\title{
Uma sombra sobre o discurso ocidental
}

\author{
Jean Hébrard \\ École des Hautes Études en Sciences Sociales \\ Paris, França \\ jean.hebrard@ehess.fr
}

Daher, Andrea. A oralidade perdida: ensaios de história das práticas letradas. Rio de Janeiro: Civilização Brasileira, 2012.

Quando os exploradores europeus chegaram pela primeira vez no Novo Mundo, trouxeram com eles uma sutil contradição: a maioria dos membros da tripulação era analfabeta, mas todos sabem que a sua religião - seja católica ou reformada - baseia-se na escrita e que a administração dos reinos de que são súditos encontra-se nas mãos de escribas. Como Colombo havia feito nas Antilhas, alguns anos antes, Cabral pisou na Terra de Vera Cruz acompanhado de seu escrivão. E nenhum deles ignorava o fato de que a tomada de posse requer algumas gesticulaçóes simbólicas, que só têm valor se alguém atesta por escrito que aconteceram. Os marujos estavam habituados a isso e deviam assistir a essa agitaçáo pacientemente à espera de que seus capitães lhes dessem o direito de exercer seus talentos babélicos com homens e mulheres que eles não entendiam - e que não os entendiam -, mas que sabiam perfeitamente trocar com eles o seus exotismos respectivos: chapéus de lã em troca de flechas de penas.

É da perspectiva da linguagem que Andrea Daher escolheu analisar a economia do encontro dos dois Mundos, que ela inscreve na estrita intrincação da negociação e da conversão (jesuíta ou capuchinha - os protestantes não se arriscaram nisso). Prova disso é a proliferação dos escritos em língua tupi que circulam desde meados do século XVI e passam incessantemente de um registo a outro do "encontro" entre o Velho e o Novo Mundo.
No entanto, essa linguagem assim exibida e este é o ponto crucial da reflexáo de Andrea Daher - é imediatamente aniquilada pelo próprio gesto que a desvela. Não é irrisório que ela se situe sob os auspícios de Montaigne e das manipulaçóes sutis desse duplo movimento de que é especialista. Quando de seu suposto encontro com os tupis que vieram visitar a cidade de Ruão, em 1555, Montaigne se queixa da rusticidade dos intérpretes que se interpóem entre ele e os índios e que impedem qualquer possibilidade de verdadeiro intercâmbio. Além disso, ele se esqueceu — diz ele - uma boa parte do que os tupis lhe disseram, mas isso, creio, para melhor sugerir o que a censura poderia provavelmente apagar de seu próprio texto.

Os missionários europeus que chegaram ao Brasil com as autoridades administrativas encarregadas de transformar algumas feitorias numa verdadeira colônia portuguesa (ou algumas paragens em verdadeiras feitorias francesas) "trabalham" a língua com a finalidade de torná-la o instrumento da conversáo das almas e dos corpos que vieram conquistar. Os jesuítas, por sua vez, "reduzem". Reduzem as línguas que ouvem em torno deles, e que muito rapidamente se tornam familiares, numa escrita e numa gramática compatíveis com as estruturas do latim para que pudessem ensiná-la em seus colégios, de acordo com as técnicas, agora comprovadamente, do "método parisiense" em que o próprio Inácio foi formado. Instalar-se na língua do outro é o "bê-á-bá" da conversão, sob uma condição: que a língua seja "desenselvajada" pelo duplo movimento de sua escrita e de sua descrição gramatical. $\mathrm{O}$ primeiro 
processo civiliza os "sons" tornando-os predizíveis e, portanto, ensináveis; mas também domestica as palavras, dando-lhes um sentido transmissível que o léxico (ou o dicionário) fixa de forma definitiva, relacionando-o à matriz latina (ou portuguesa) do mundo dito. O segundo passo abre caminho para a possível geração de enunciados vindos de fora da palavra tupi, enunciados novos, inauditos, passíveis de transformar radicalmente a cultura de que aquela língua provém, de "reduzi-la". Ao mesmo tempo que trabalham a língua dessa forma, os jesuítas operam de modo idêntico no espaço tupi e nas sociabilidades por ele estruturadas: eles "reduzem" a vida tupi à aldeia, esse lugar de vida centrado em torno da igreja, cujo sino dá o ritmo das horas do dia em que trabalho e oração se alternam, cerradamente, de modo a eliminar (ou tentar eliminar, ao menos) todo e qualquer traço do modo de fazer, de sentir e de pensar que não estejam ajustados à ordem europeia e cristá.

Os franceses, sejam eles protestantes como Jean de Léry ou católicos como os capuchinhos Claude d'Abbeville e Yves d'Evreux, têm outras maneiras de fazer. É verdade que o primeiro pensa pouco em converter e que os segundos chegam mais tarde num terreno já amplamente semeado pela missão jesuíta. Além disso, ao contrário dos companheiros de Loyola, o ensino não é a principal preocupação de nenhum deles, até mesmo por náo ser o instrumento principal de sua atividade. Vindos com os comerciantes normandos que, acima de tudo, buscam assegurar o monopólio das relaçóes com as tribos que aceitam os sistemas de escambo que propóem, os franceses estão mais interessados na possibilidade de sua ação do que em sua ação em si. E, desse ponto de vista, observam e descrevem mais do que agem. Como Lévi-Strauss observou sobre Jean de Léry, eles inscrevem o mundo tupi numa espécie de curiosidade antropológica. Andrea Daher diz mais que isso, e com razão, que esse olhar distante concentra-se, primeiro, nos signos da convertibilidade econômica ou religiosa dessas populaçôes, sua convertibilidade diplomática, quando se trata de tomar os tupis aos portugueses. No entanto, para os franceses, é a palavra tupi que é o seu receptáculo e, portanto, o signo. A prova do sucesso da missáo, como o da colonização, encontra-se nessa palavra relatada, transcrita e interpretada. Ora, o próprio ato que a torna inteligível, mais uma vez, e através de instrumentos outros do que aqueles utilizados pelos jesuítas, apaga irremediavelmente o que ele pretende testemunhar.

Em ambos os casos, trata-se, de fato, de "práticas letradas" - como o subtítulo do livro indica — que permitem "perder" essa oralidade e, com isso, o instrumento que produz essa erradicação é precisamente o mesmo que mantém sua memória e permite que o historiador rastreie a sombra que dele se projeta sobre o discurso ocidental.

Após uma introdução que trata da tensão entre escrita e oralidade nas práticas letradas abordadas no livro - breve, porém incisiva —, a segunda e a terceira partes inscrevem-se nessa lógica: redução das línguas indígenas à "língua geral” inventada pelos jesuítas, inscriçấo dos discursos proferidos em língua geral no corpus de relatos franceses que, dos canibais ao bom selvagem, fundam - em parte, porém de modo eficaz - o discurso ocidental sobre a alteridade colonial. A quarta parte consiste num estudo inesperado, mas muito bem-vindo, dos "usos do tupi em projetos político-culturais e programas literários oitocentistas" (p. 36). O livro se fecha, na quinta parte, com uma reflexão sobre "a monumentalização das narrativas 'antigas', que faz com que sejam tomadas, anacronicamente, como testemunhos objetivos de uma realidade subjetivamente observada no passado, para fins expressamente críticos e de forma inevitavelmente nostálgica" (idem).

Como se pode ler nos primeiros "ensaios", nos quais se concentra esta resenha, a hagiografia jesuíta afirma que o padre Anchieta - que secretariou Nóbrega, superior da missão jesuíta que chegou em 1549 no mesmo barco que o governador Tomé de Souza - tinha um dom de línguas tal, que em poucos meses aprendeu o tupi e escreveu a sua gramática. A partir de 1560, ela foi ensinada no Colégio da Bahia. A teologia do Pentecostes é inseparável do espírito da missão: o Espírito Santo oferece àquele que por ele é santificado a sutil arte de fazer existir a Palavra em todos os idiomas. 
No entanto, a experiência brasileira nos ajuda a compreender que todas as línguas não são passíveis, no mesmo grau, de permitir esse transporte ou, mais precisamente, que elas devem passar por várias transformaçôes antes de ser possível fazê-lo. O prefácio do Catecismo de Trento permite entender o porquê. Os padres conciliares explicam que o conhecimento dogmático contido no texto catequético e nas principais oraçôes (a "ciência da Salvação") obviamente não é acessível de imediato ao catecúmeno, mas que ele terá tempo, domingo após domingo, para penetrar um pouco mais em sua significação, à medida que o padre, em sua homilia, a expuser. $\mathrm{O}$ que se espera de um cristão é, simplesmente, que grave o texto em sua memória. Para fazê-lo, ainda é preciso que a língua que carrega esse texto seja suficientemente estável para que, com o tempo, a significação não seja alterada. Encerrá-la numa gramática e num dicionário e, em seguida, num corpus exemplar de textos validados pelas censuras civis e eclesiásticas deveria ser suficiente para garantir essa estabilidade. Ao optar por fazer com que as línguas vernáculas ocupem um lugar ao lado do latim (como fez a Reforma que, de algum modo, impôs o modelo), a Igreja assumiu um risco. Como mostra perfeitamente Andrea Daher, a continuidade das operaçóes linguísticas que gramaticalizam as línguas vernáculas se estende às línguas do império colonial: Nebrija e Anchieta fazem parte da mesma lógica. Agir sobre a língua é, de alguma forma, certificar-se de que a palavra será submetida. A inconstância dos tupis, tantas vezes invocada para justificar a pouca eficácia da catequese realizada pelos incansáveis "operários de uma vinha estéril”, poderia ser curada com a substituição de uma "língua geral" à sua língua materna. É o que propóe Anchieta, educando as crianças dos tupis conversos ao idioma que ele inventou. Andrea Daher, baseada em Jack Goody, sugere que a língua geral opera uma descontextualização das línguas vernaculares e, como tal, é instrumento de uma aculturação violenta. Certamente, dos anjos aos pastores e suas flautas, essa descontextualização faz com que alguns personagens muito estranhos ingressem no mundo tupi. No entanto, mais ainda, ela submeteu a palavra viva ao jugo do léxico, das formas sintáticas e dos tropos com que o jesuíta fabricou essa quimera.

Do lado francês, o procedimento não é idêntico. Por um lado, os franceses não têm essa ampla continuidade que sustenta o trabalho dos jesuítas estabelecidos no âmbito português. Por outro lado, as duas tentativas de colonização francesas, a França Antártica (Jean de Léry e Villegaignon, na baía de Guanabara, em 1555) e a França Equinocial (Claude d'Abbeville e Yves d'Evreux, na ilha do Maranhão, em 1612), não têm os mesmos objetivos. De Lévi-Strauss a Frank Lestringant, passando por Michel de Certeau, o texto de Léry foi abundantemente comentado. Inscrevendo-se plenamente nos debates entáo suscitados, Andrea Daher chama a atenção para um ponto, $a$ priori menor, porém esclarecedor. Léry preferiu o método erasmiano de encenação da língua num "colóquio", uma conversa, ao método jesuíta de gramaticalização da língua. $O$ gênero textual consiste tanto num manual de ensino de uma língua falada quanto num breviário do viajante que chega num país de que não conhece a língua (os comerciantes europeus produzem muitos, desde o século XIV), e no clichê ilustrativo que, ao lado das xilogravuras, acompanha o relato de viagem. Nesse caso, sua brevidade permite situá-lo melhor do lado do exotismo linguístico. No entanto, como observou habilmente Andrea Daher, Léry acrescenta uma nota inesperada. Ele se coloca na cena do colóquio em que transcreve seu próprio nome em língua tupi através da homonímia que lhe atribui o lugar de grande-ostra (Léry-Oussou). Os viajantes que chegaram à China e ao Japão, na mesma época, adoravam, do mesmo modo, se atribuir um ideograma que associasse o seu patrônimo a um ser estranho do mundo para o qual tinham viajado. A língua do outro se torna o pano de fundo da identidade daquele que a estabelece ao transcrevê-la. A operação da ostra-Léry lembra aquela de que Hans Staden lança mão, no mesmo momento, para relatar a seus contemporâneos a aventura extraordinária que viveu no Brasil. Tendo embarcado para essas partes para fazer negócio e sido capturado pelos tupinambás, Staden es- 
capa ao festim antropófago, porém descreve todas as suas etapas e pede a um gravador alemão para representá-lo em meio àqueles com os quais compartilhou, meses a fio, os ritos e a linguagem. $\mathrm{Nu}$ como eles, enfeitado como eles, inserido na mesma paisagem e nas mesmas açôes, perdido em sua alteridade, distingue-se apenas pela barba que aparece desenhada. Como Léry, ele não conseguiu resistir ao fascínio da identificação. Mas também como Léry, foi para melhor dizer a sua incomensurabilidade em relação a seu próprio mundo. Para Léry, a antropofagia dos tupis é o sinal de sua danação; para Staden, é o sinal da inconvertibilidade dos produtos brasileiros, dentro das regras de um comércio ordenado.

A proximidade das duas modalidades de convertibilidade de valores (religiosos e econômicos) também está no centro do olhar lançado, um século mais tarde, pelos capuchinhos franceses sobre os tupis do Maranhão. Na sua Suitte de l'histoire des choses les plus mémorables [Continuação da história das coisas mais memoráveis], de 1615, por exemplo, Yves d'Evreux encena diálogos (bilíngues) que mantêm um francês recém-chegado e um tupi, citados no livro. Ele atribui ao francês alguns termos tupis que expressam a confiança adquirida: "Erei potar touroumi? (...) Queres dormir?" (citação, p. 114). Mas ele se instala na "palavra interior" do índio para fazê-lo pensar, em francês, o que o europeu espera dele: "Eis que chegam os navios de França (...), hei de ser bom compadre: ele me dará machadinhas, foices, facas, espadas e vestimenta; eu lhe darei minha filha, caçarei e pescarei para ele, farei muito algodão, procurarei plumas de garça e âmbar para dar-lhe (...)" (idem). Os termos do escambo são franceses. A palavra tupi encontra-se em seu melhor estado quando está adormecida. O escambo religioso é encenado de acordo com os mesmos tropos. Numa passagem magnífica da Histoire de la mission des pères Capucins [História da missáo dos padres Capuchinhos], de 1614 - que narra a viagem à França de índios trazidos ao rei, em 1614, e que evoca o seu batismo seguido da morte de três deles —, Claude d'Abbeville dá a palavra ao índio Carypyra, em sua língua, para dizer os milagres produzidos pela sua conversão. No entanto, para introduzir esses termos tupis, reproduzidos com muito cuidado pelo impressor parisiense, ele escreveu em francês: "Tão logo batizado, ele virou o rosto para a parede, permanecendo num grande e longuíssimo repouso: e como despertado deste profundo silêncio, largou num suspiro as seguintes palavras (...)" (citação, p. 126). A opacidade da transcrição ortográfica, cujas regras de pronúncia permanecem um mistério, faz desse enunciado uma espécie de quadro sem vida, que o silêncio subsume melhor do que a tradução que segue a transcrição da fala em tupi. Se os jesuítas "reduziram" as línguas tupis para torná-las ensináveis, os capuchinhos exibem suas palavras como ex-votos das conversóes supostamente bem-sucedidas. Eles entenderam que a língua geral não tinha outro interesse que não fosse o de produzir ou de constatar o afrancesamento econômico ou religioso do mundo tupi.

Esse instrumento importante da colonização europeia das Américas que foi a transcrição e a redução gramatical das línguas autóctones não desapareceu quando os imperialismos linguísticos ibéricos impuseram o castelhano ou o português a suas colônias. Ele simplesmente mudou de cena. O século XVIII tornou-o uma das curiosidades expostas nos "quadros" das línguas do mundo suscetíveis de medir o grau de degradação introduzido nas línguas vulgares pós-babélicas em relação à matriz hebraica. $\mathrm{O}$ romantismo constatou sua morte, a fim de mostrar melhor a eficácia retórica de uma língua literária nova que viera se recarregar na costa ocidental do Atlântico. Ferdinand Denis - este extraordinário apaixonado pelo Brasil, que após uma curta viagem (1816-1820), nunca deixou de narrar, de seu observatório na Bibliothèque Sainte-Geneviève, as suas maravilhas - escreveu, no entanto, mais de um século antes de Lévi-Strauss, em outros termos, evidentemente, em Scènes de la nature sous les tropiques: "Vi os restos dessas tribos infelizes a errarem pela terra de seus antepassados. Elas se debilitam dia a dia e logo terão desaparecido dos lugares onde eram temidas, e seus gritos de guerra não mais farão ressoar as imensas florestas do São Francisco e do Belmonte que, por sua vez, começam a cair sob o machado do infeliz africa- 
no" (citação, p. 200-201). Entretanto, no mesmo movimento, pede aos poetas dos dois Mundos que tomem os tropos dessas línguas para torná-los os materiais da revolução romântica: "Se, como disse o Sr. Humboldt, a influência da natureza é tanto mais sensível quanto mais o homem se encontrar afastado da civilização, não se pode deixar de ver que este pensamento encontra aqui nova aplicação e que vem apoiar o que ouso avançar. Os povos situados nas zonas mais ardentes são aqueles aos quais a natureza reservou inspiraçóes poéticas" (citação, p. 199). Andrea Daher faz com que se reviva sob nossos olhos essa guerra das línguas conduzida sem trégua nas missões das Américas. Como mostra com grande elegância, o duplo movimento de transcrição e de apagamento deixa como uma sombra vestigial em que a oralidade perdida continua hoje a se fazer ouvir. 